\title{
FEMINISM AND QUEER Temporal Complexities
}

Marianne Liljeström

A widely recognised view concerning the relationships and exchange between feminist and queer thinking states that feminism is chronologically "older" than queer theory, as queer emerged precisely as a critique of identities, whether gendered or sexual. Simultaneously, it has been noted that shifts in feminist and queer theories and academic practices have modified differences between the two in terms of both alleged and taken-for-granted dissimilarities. This claim requires an examination not only of customary variances, but also of current, factual differences between these theories.

In this article, first I pay attention to the ways in which feminist and queer theories have become closer and more theoretically intermixed together with the strengthening of identity critique. Second, I connect this discussion to the impossibility of thinking about the categories of gender and sexuality as separate and, to some extent, to the establishing of trans theory and scholarship, multiplying our understandings of genders and sexualities. Third, I take a closer look at the broadening of the subject areas of queer scholarship. Fourth, this leads me to a questioning of the temporal movements between these two strands of theoretical thinking. I ask, how are we today convincingly showing that they differ from each other? Or, are they so intertwined that we can talk about both queer feminism and feminist queer thinking?

\section{ABSTRAKTI}

Laajasti hyväksytyn näkemyksen mukaan feminismin ja queerin suhde ja vaihdanta todistavat feminismin olevan kronologisesti queer-teoriaa vanhempaa, koska queer on nimenomaisesti syntynyt identiteettien, joko sukupuolisen tai seksuaalisen, kritiikistä. Samanaikaisesti on noteerattu feminististen ja queer-teorioiden sekä akateemisten käytäntöjen siirtymien muokanneen termien välisiä oletettuja ja itsestään selvinä pidettyjä eroja. Tavanomaisten erojen toteamisen sijasta tämä väittämä vaatii ajankohtaisten ja todellisten erojen tutkimusta.

Ensiksi kiinnitän huomiota vahvistuneen identiteettikritiikin aiheuttamiin feminismin ja queer-teorioiden lähentymisiin ja toisiinsa kietoutumisiin. Toiseksi tuon keskusteluun näkemyksen, jonka mukaan on mahdotonta ajatella sukupuolta ja seksuaalisuutta toisistaan erillisinä, sekä jossain määrin myös trans-teorian ja sen avaaman uuden tutkimusperinteen, joka on moninkertaistanut ymmärryksemme sukupuolista ja seksuaalisuuksista. Kolmanneksi tarkastelen lähemmin queer-tutkimuksen aihealueiden kasvua. Neljänneksi pohdin näiden kahden tutkimusperinteen välisiä ajallisia liikkeitä. Kysyn, voimmeko uskottavasti erottaa niitä toisistaan. Vai ovatko ne niin toisiinsa kietoutuneita, että voimme puhua sekä queer-feminismistä että feministisestä queer-ajattelusta.
QueerScope Articles 
In discussions about the relationships and exchange between feminist and queer thinking, two self-explanatory views keep resurfacing in the academic debate. ${ }^{1}$ On the one hand, feminism and queer are considered resolutely linked by their focus on the construction and deconstruction of the naturalised and binary categories of gender and sexuality (see, among many, especially Butler 1993, 1994; Rudy 2000; Jagose 2009; Marinucci 2016). On the other hand, feminism is seen as temporally and chronologically "older" than queer, the reason being that the latter emerged precisely as a critique of the identities that feminism supposedly assumes, sexual but also gendered. Because of these linkages, there are among queer/feminist scholars - besides an increasing curiosity in thinking about queer temporalities (see, for example, Jagose 2007; Freeman 2010; Halley \& Parker 2011) - a growing interest specifically in the historical interconnectedness between these two strands of critical thinking.

Queer and feminist theories have been habitually put in opposition to each other by assigning them "proper objects" of study, gender being the proper object for feminism and sexuality for queer studies (see Butler's critique 1994, 1-26). They have been distinguished from each other not only in connection to the question of (stable) identities, but also as having a different understanding of the meaning and manifestations of sexuality. However, an increased problematising of the interconnectedness between the categories of sexuality and gender has made feminism more "open" to the problematics of sexuality (Butler 1990, 2004). This conceptual intertwinement has also had an effect on the growing impetus of trans studies - and queer theory today pays more attention to gender and its plasticity (Richardson 2006, 24-26; Berger 2014, 75-77).

1 See, above all, de Lauretis (1991), Rubin (1993), Butler (1993), Weed (1997), Richardson et.al. (2006), Halley \& Parker (2007) and Wiegman (2012).
Connections arise also from the complex interchange between the ways in which feminist and queer theory both are defined and understood through terms related to sexual desire and pleasure.

In this article, my interest in thinking about the connections between feminism and queer - hardly a new discussion - stems especially from the curiosity regarding examining their temporal (historical) bonds. Nevertheless, in thinking about their connections, it is difficult to avoid mapping, defining and discussing differences between the two strands, that is, it is impossible to dismiss shifts and moves within and between feminist and queer theories and those academic practices that have modified both alleged and taken-for-granted dissimilarities. My focus in this article is on those possible alterations, turns, adjustments, modifications and twists in the relations between feminist and queer thinking that occurred because of emerging timelines, new concepts and names, and factual changes concerning the growing and more acceptable attitude societally to gender and sexual multiplicity.

Due to the abundantly fruitful and very productive critical scholarship, be it feminist, queer or queer feminist, thinking about the intertwinement of these strands of thought is a huge topic. I limit my discussion here to the following. First, I discuss changes concerning definitions and understandings of identities. However, because feminist thinking both historically and currently is considered to be "still" invested in the category of woman/women, many see it as a melancholic and outdated way of relating to the world (Ahmed 2017, 155). Then again, if feminism "always" can be considered to have been queer ("non-normative") - according to a broad definition of queer - the "problem" has just been the identity category of "woman/women". Second, I connect this discussion to the impossibility of thinking about the categories of gender and sexuality as separate and to the assigning of multiplying understandings of genders 
and sexualities to trans theory and scholarship. Third, I take a closer look at the broadening of the subject areas of queer scholarship. Fourth, this leads me to the question of temporal movements between queer and feminist theory. Using the Finnish discussion as an example, I ask: How do we today convincingly show that they differ from each other? Or, are they so intertwined that we can talk about both queer feminism and feminist queer thinking?

Thus, I discuss the ways in which feminist and queer theories have become more intimate, and more theoretically mixed, along with a shared concern regarding identity critique and the growing acceptance of the multiplicity of genders and sexualities. With these connections and the similarities and differences between feminist and queer theory in mind, my overall aim is to underline temporal movements other than those of linearity and its dependence on generation, teleology and heteronormativity. However, in discussing the growing closeness of feminist and queer theories, my focus concerning shifts in and new emphases on this interconnectedness is on the role of queer theory. This does not mean that I consider feminist theory in any way unaltered or secondary in this entanglement, but a focus on feminist theory would require a different focus and another discussion. The same concerns localising and describing queer research in a Finnish context: my brief reflexions and minor comments concerning Finnish circumstances are included primarily as expressions and illustrations of one context maybe worth investigating.

The understanding and specification of the relations between the two theoretical strands are dependent on the articulated theoretical and interpretative position. We can differ between definitions of queer as a substantial term, which links it to sexual and gender deviancy and to identity politics, and as a more theoretical term describing a spacious non-normativity and questioning the notion of identity (see Sedgwick
1994, 9; Rossi 2017, 6). The latter definition is the realm within which I situate myself in this article. Furthermore, I also distinguish between the terms queer thinking/theory/scholarship and queer studies. The first three terms are general and wide ranging and I use the notions interchangeably. I will not use the concept of queer studies, because I think that it points to an institutionalised view of an academic practice. There is no space for dealing with the question of institutionalisation here, but it can be noticed that much queer scholarship falls within gender and feminist studies, at least in Finland and Sweden, in spite of the fact that in neither country are there any explicit, named academic departments for Queer Studies.

\section{Multiple identities and genders}

According to Robyn Wiegman, feminism is a pre-institutional discourse, and queer theory a critique, of the ways that identity became institutionalised in academia (Wiegman 2004, 107). Thus, she sees queer theory as an effect of identity's transformation from a (feminist) discourse of political change to an object of study and part of the shift from a study of social movements to the formation of an academic field. The critical force of queer theory therefore required the prior arrival of both gendered and sexual identity onto the academic scene as an arena of inquiry (Wiegman $2012,117,121)$. Hence, Wiegman creates a chronology for queer and feminism, a casual temporal link between them. However, if one extends the definition of queer to involve such characteristics of feminism as critical thinking and a continuing negotiation of its own categories, terms and points of departure, then Wiegman's view of causality seems problematic.

Critical approaches to the elaboration of the identity category of "woman" as a universal category - often inspired by queer theory - sparked heated intra-feminist debates, particularly in the 1990s, and many hence saw 
them as a sign of grave crisis. The "crisis label" had followed feminism for decades. As many scholars have noticed, almost immediately after its emergence in the 1960s critics began claiming that feminist theory was said to be in a state of conflict and "crisis" (see, e.g. Kaplan 1992; Wiegman 2000; Jagose 2009; McBean 2016, 1-14). The alleged crisis in feminist theory coincided quite closely with its rise to prominence. The "crisis talk" came both from "outside" feminism and from "inside" it (Hirsch \& Keller 1990, 370-80; Elam \& Wiegman 1995, 1-8). This was also strengthened by feminism's self-reflexivity, which meant that scholars in the field not only questioned their own theoretical and political presuppositions, but also elaborated on and reinforced the very gesture and process of selfquestioning (Koivunen \& Liljeström 1996, 13-17). For example, the rise of gender theory/gender studies ${ }^{2}$ within and as a part of academic feminism has been seen simultaneously as a sign of "crisis" and as a solution to some sort of previous "crisis".

When the task of feminist theory shifted from studying women to studying gender as a set of relations, gay and lesbian studies analogously moved from tracing historically stable identities based on object choice to defining queerness in relation to sexual norms (Kekki 2003). These parallel shifts have created intersections between queer and feminist scholars who share gender and sexuality as objects of analysis (Marcus 2005, 195). The act of embracing queer as an unspecified conceptual umbrella, one unifying outlaws and all kinds of outsiders, suggested that complex identifications and differences undermine identity claims. Sharon Marcus has noticed that while queer foregrounds the belief that sexual identity is fluid and unsteady, feminism, gay and lesbian views do not assert the contrary (ibid). Seen from

2 I limit my discussion here to (Anglophone) gender theory, leaving, among other approaches, sexual difference theory unheeded. The impact of gender theory on Finnish, and in general on Nordic, feminist thinking has been most strong (Dahl et al. 2016) this perspective, the "classic", often intensively reproduced, contradiction between the positions seems rather outdated. On the other hand, the fact that queer also has become an identity marker in lieu of the acronym LGBTIQ nonetheless highlights the identitarian attachments of queer.

Another focus on the relations between feminist and queer theory concerns queer's emphasis on an anti-identitarian "universalism" as opposed to feminism's identity-focused "particularism". This distinction is seen in Lee Edelman's statement "queerness can never define an identity; it can only ever disturb one" (Edelman 2004, 17), wherein queer is pictured as a horizon of its own impossibility as an identity. This means, as Madhavi Menon has stated, that in answering the question of what is queer, one cannot focus on a set of visible, embodied differences to mark something, be it people or events, as queer (Menon 2015, 18). Furthering this thought, Menon stresses that if we consider that queerness, at a minimum, refuses the pre-determinability of identity, then we are immediately in the domain of the "universal", something which according to her announces itself as a queer meaning empty of content, and therefore, revolutionary (Menon $2015,18)$. According to her, the notion of universalism also suggests that queerness is universal, because it "refuses to settle in a country or language or colour or dress or gender" (Menon 2015, 18). Menon claims that what is queer about queer theory is "its ability to recognize and sympathize with longings across borders; to refuse the logic of particularity in relation to desire; to keep the door universally open rather than shutting it behind our backs; to think of desire as that which moves across rather than being confined to sexual acts and identities" (ibid, 127).

If one operates with these terms of universal versus particular in accordance with Menon's line of thinking, the assumed universalist character of queer as opposed to the particularity of feminist thinking results in a challenging order of reciprocal importance between them: queer theory is seen as much 
broader and encompassing than feminist thinking. In accordance with this line of thinking, it becomes clear why there has been an abundance of discussion about "the queer turn in feminism", about "feminism's queer theory" and about "feminism as queer", whereas we hardly find any texts discussing "the feminist turn in queer theory", "queer theory's feminist character" or "queer as feminism". ${ }^{3}$ Besides revealing an aspect of the hierarchic relationship between the general and the specific, this circumstance is also interesting in relation to problematising the temporal movements of feminism and queer. KUVA (Spartacus ja Degas)

\section{Sexuality and gender as research objects}

It has been customary to present the origin of queer theory as linked to the simultaneous publication of Judith Butler's Gender Trouble (1990) and Eve Sedgwick's Epistemology of the Closet (1990). ${ }^{4}$ Both works challenged a certain heterosexist bias at work in feminist theory, as a theory about gender. Besides this challenge by Butler and Sedgwick, a highly influential 1984 article called “Thinking Sex" by Gayle Rubin, which elaborated on the distinction between gender and sexuality, is also considered one of the inaugural acts in defining queer theory (Love 2011b, 1-14; Wiegman $2012,96) .^{5}$

3 However, in Sweden, Tiina Rosenberg, one of the earlier influential voices in the debates about queer, defined herself as queerfeminist because of her primary interest in the relation of queer theory to feminism. Pretty much in line with Linda Garber's thinking (Garber 2001), Rosenberg declared, with explicit reference to identity categories, that "the lesbian feminists are the brain behind queer theory" (Rosenberg 2003, 21).

4 The first queer conference "Queer theory: Lesbian and Gay Sexualities", was held in Santa Cruz, CA, in 1990; see the Summer 1991 special issue of differences, edited by Teresa de Lauretis. See also Hennessy (1993).

5 Michael Hames-García has presented a thought-provoking critique of this genealogy $(2011,21-25)$.
In order to make a distinction between feminist and queer theory, an epistemic habit occurred where queer and feminism were juxtaposed schematically, with the former focusing on mobile and "flexible" ("male") sexuality and the latter on an immobile and "stable" ("female") gender. Already in 1992, Biddy Martin, in her article "Sexualities without genders and other queer utopias", expressed concerns about this distinction and separation between feminist and queer theories (Martin 1994). However, as various publications demonstrate, the analytical relationships between sexuality and gender are quite complex. For example, Annamarie Jagose underlines the fact that gender is implicated in sexuality, but sexuality cannot be comprehended from within any of the various deployments of gender. The analytical separation of gender and sexuality is increasingly considered controversial (Jagose 2009). Separating sexuality and gender means that critical inquiry becomes inattentive to the degree to which a normative reproduction of gender supports and enables the regulation of sexuality. Both feminism and queer theory have a stake in desiring and articulating the complexities of the traffic between gender and sexuality. As Robyn Wiegman has noted, today we do not have to deliberate about gender as something stationary or stagnant in relation to mobile sexuality: we do not need to render gender analytically secondary in order to articulate sexuality, precisely "because we do not need to reduce gender to its dimorphic ascriptions" (Wiegman 2012, 131-32). The expanding field of trans scholarship has successfully explored this matter (Stryker \& Currah 2014, 1-18). Susan Stryker wrote in 2004 that trans studies was "queer theory's evil twin". However, she has refused to construct queer, trans and feminist studies in opposition to each other. According to her (along with Paisley Currah and Lisa Jean Moore), trans scholars' goal is to

6 In a dialogue between Andrea Long Chu and Emmett Harsin Drager, Chu insists, provocatively and quite ironically, that Stryker was wrong: "Trans studies is the twin that queer studies ate in the womb. The womb, as usual, was feminism" (Chu \& Drager 2019, 103) 
take feminist scholarship into expansive new directions by "articulating the interrelatedness and mutual inextricability of various 'trans-'phenomena" (Stryker et al. 2008, 12). Already for some twenty years, an occasionally heated debate has been ongoing within trans studies regarding its relationship to queer theory: it has been asked whether "transgender" can fit neatly into a conceptualisation of queer theory (Chaudhry 2019, 45). In a review essay about rethinking transgender in queer theory, $\mathrm{V}$ Varun Chaudhry has emphasised that by focusing on the numerous iterations of "trans" in a variety of contexts, transgender studies must contend with its complicated historical and present-day reality. According to him, queer studies must take the lead from transgender studies (and not the other way around): rather than being new, trendy and theoretically sexy, "trans studies has always been there, often lurking in the theoretical shadows, with little attention or resources to back up its importance" (ibid., 49). Thus, he underlines, fully contending with the "transgender moment", that queer studies must attend to the packed, messy and institutionally fraught picture of the "category itself" (ibid).

In an attempt to trace genealogies of transfeminism in France and Spain, Karine Espineira and Marie-Hélène/Sam Bourcier, who call for an inclusive feminism and criticise "Anglo white" queer theory "and its capacity for disembodiment", interestingly argue that transfeminism is about not only resignification but also rematerialisation. For them, a new focus on the body through trans and crip theories takes transfeminism where a "disembodied" queer theory has failed to go (Espineira \& Bourcier 2016, 84, 88).

Wiegman as well suggests revising feminist and queer critical discourses of sex, desire and embodiment, yet she urges us to explore gender's erotic significations as a matter of transitivity (Wiegman 2012, 132). Gender transitivity is accentuated as an especially desirable political expression of queerness in sharp contrast to the intransitivity of the binary heteronormative understanding of gender. Already in Epistemology of the Closet (1990), Eve Sedgwick pointed to the historically and conceptually un-nuanced way in which definitions of sexuality depend somewhat exclusively on the gender of the object choice, assuming that one's gender and the gender of those one is sexually attracted to mark the most significant facet of human sexuality (Sedgwick 1990, 35). As is well known, Sedgwick made, in her understanding of same-sex relations, a division between minoritising/universalising, ${ }^{7}$ correlating them with gender transitivity versus gender intransitivity. She points out that a gendering of homosexual desire can be dealt with through two oppositional understandings: first, a transitive understanding according to which desire originates in a threshold space between gender categories, and second, a separatist, intransitive understanding, according to which desire's expression is either masculinity or femininity (ibid, 17).

In continuing to elaborate on the terms gender transitivity and intransitivity, Wiegman asks: How precisely are we to understand dimorphic gender (i.e. the distribution of two sexes as two genders) as intransitive? According to her, heteronormativity inherited and mobilised an enormous cartography of sex and gender whose transitivity it reworked to suit its own outstanding and intransitive ends, thus giving us dimorphic heterogender (Wiegman 2012, 317).

For Wiegman, just as for Sedgwick and many other contemporary feminist and queer theorists (e.g. Marcus 2005; Halley \& Parker 2011; Berger 2014), any configurations of sex and gender have always been transitive

7 Sedgwick explains the views as "seeing homo/heterosexual definition on the one hand as an issue of active importance primarily for a small, distinct, relatively fixed homosexual minority, ... and seeing it on the other hand as an issue of continuing, determinative importance in the lives of people across the spectrum of sexualities..." (Sedgwick 1990, 1) 
and always about some version of historically specific mobile routes of gender and sex (Wiegman 2012, 317-318). Wiegman's conclusion that gender is constitutively and innately transitive in terms of both its embodied productions and the circuits of desire ends with a claim that maybe the matter was not about a queer desire for gender transitivity in the first place, but for gender itself. She writes that "the heteronormative insistence that gender serves as the privileged mode of signifying the meaning of sex - and hence that gender is the body's meaning — is part of a broader, if contradictory, social and psychic desire for gender" (ibid., 323 , her italics). This desire is, according to her, energised by profound, incommensurate and proliferating investments in the look and feel, the language and symbolism, the erotic life and the everyday manifestation, as well as the mutability and transitivity of gender (ibid).

I find her discussion stimulating but also quite puzzling: What then is the difference between the desire for gender and the desire for gender transitivity, if we understand gender as transitive, as a beautiful gamut? Then, all kinds of sexual orientations and desires always also contain and encompass a desire for gender. However, the escalating understanding of gender as inherently transitive seriously questions heteronormative assumptions about gender intransitivity and the ways in which these assumptions reduce gender to its dimorphic qualities and classifications. Understanding not only sexuality, but also gender, as profoundly transitive and mobile necessarily has the effect of bringing feminist and queer theory into a more intimate exchange of ideas.

\section{Expanding the area of queer investigation}

In looking at the contemporary subject area of queer theory, Janet Halley and Andrew Parker quite polemically ask in their introduction to the anthology After Sex? On Writing since Queer Theory if a work can be regarded as queer if it is not explicitly about sexuality (Halley \& Parker 2011, 1-2). This question receives a "classic", often-cited affirmative answer in David Halperin's words: "Queer is by definition whatever is at odds with the normal, the legitimate, the dominant. There is nothing particular to which it necessarily refers" (Halperin 1995, 62). In line with this statement are David Eng, Judith Halberstam and José Muñoz, who in their call for a "renewed queer studies" write that " $[\mathrm{w}]$ hat might be called the 'subjectless' critique of queer studies disallows any positing of a proper subject of or object for the field by insisting that queer has no fixed political referent" (Eng, Halberstam and Muñoz 2005, 1, italics theirs). However, differing from these perspectives, Eve Sedgwick wants, for political reasons, to retain connections between queer and gay and lesbian sexualities. She thinks that to displace same-sex object choice from the definitional centre of the term "would be to dematerialize any possibility of queerness itself" (Sedgwick $1994,8)$. On the other hand, this conclusion does not prevent her from expanding on an understanding of the term: "a lot of the most exciting recent work around 'queer' spins the term outward along dimensions that can't be subsumed under gender and sexuality at all. (...) Thereby, the gravity $(\ldots)$ of the term 'queer' itself deepen and shifts", she writes (ibid., 8-9).

In line with Sedgwick's statement, today we can see characterisations and understandings of queer scattered and spread out in a variety of directions. In this section, I look at some of them, starting from an epistemological queering of such a comparison, then linking it to universalism and to thinking about the non/human and inhuman. The aim here is to show how broad the subject area of queer investigation (sometimes in accordance with feminist analyses, but also quite often as separate from them) is understood to be. 
While Halley and Parker underline that queer theory's powers are practical and political, not epistemological (Halley \& Parker 2011, 8), the approach of the volume Comparatively Queer (2010), edited by Jarrod Hayes, Margaret Higonnet and William Spurlin, quite significantly differs from this point of view. In their introduction, the editors declare that the aim of the book is to put comparison back into comparative studies as one way of queering these studies. Their starting point is the statement that if queer differs within different contexts, it may be considered a concept that is capable of crossing both time and cultures (Hayes et al. 2010,2).This means that it should be deployed comparatively, the key to which lies in the "in-between" that the crossing creates. In her afterword to this anthology, Valerie Traub thus remarks that the concept of queer seems to function less as a point of dispute than as a working assumption, standing in for non-normative erotic acts and identities in general and same-sex ones in particular (Hayes et al. 2010, 217).

Furthermore, in the anthology Queering the Nonhuman (2008), edited by Noreen Giffney and Myra Hird, the point of departure in the usage of queer as a critical theory is also employed as a collection of methodologies for unpacking binaries and rereading gaps, silences and in-between spaces. The aim with queering the non/human is to further broaden and diversify the scope of queer. While the editors are reluctant to say just what queer "is", they think that what queer "does" concerns priorities, genealogies and aims. By queering the non/human, the book wants to queer queer theory itself (Giffney \& Hird 2008, 4-6).

While the above-mentioned anthology explores the overlap between queer studies and expanding interest in the nonhuman, the editors of a special issue of GLQ, "Queer Inhumanisms", begin their introduction by asking, has queer ever been human? (Luciano \& Chen 2015, 186). Their answer is yes, and no. Yes, because the unjust dehumanisation of queers posits the human as standard form and because many thinkers have privileged the human body and sexuality as the locus of their analysis. No, because queer theory has been suspicious of the politics of inclusion to which liberal-humanist values lead and because "full humanity" has never been the only horizon for queer-becoming (ibid., 188). Dana Luciano and Mel Chen emphasise that this approach to queer theory does not declare an identity so much as it stages an encounter; the engagement with the inhuman expands the term queer, in their opinion, past its conventional resonance as a container for human sexual non-normativities (ibid., 189).

In contrast to the broader application of queer theory/queering as methodology, some theorists see the fruitfulness of the concept applied on metatheoretical and philosophical levels. For example, as mentioned earlier, Madhavi Menon links the concept of queer to the question of how universalism can be approached. By seriously questioning queer's connection to identity or identities, she asserts that " $[\mathrm{e}]$ verything is queer because no-thing (peoples, events, desires) can achieve ontological wholeness" (Menon 2015, 19). Despite this statement, Menon asks if queer theory's capaciousness has gone "too far" and whether queerness has any specificity, or whether everything (and, therefore, nothing) is queer (ibid., 123). Her understanding of universalism focuses on queerness as something that refuses the predetermined cohesion of identity, which in her view moves queerness immediately to the domain of the universal. Because queerness refuses the regime of identitarian truth, "a queer universalism does not belong anywhere, and it is owned by no one” (ibid., 127).

Within queer thinking, there has been a move away from examining minority sexual identities toward a more general theorising of sexuality, where queer has been conceptualised in manifold ways, for example in Deleuzian terms as a "force" or "energy". In general, it is easy to notice that the universalising strain of queer scholarship has significantly expanded 
in recent years (Love 2011a, 181). Queer is moving away from both evidentiary claims about same-sex desire and acts and from a specific focus on gay and lesbian people. Queer is, as Heather Love has wittily noted, "not only also about race, class, gender, ethnicity, and nation, but is also about affect, citizenship, the death drive, diaspora, digitality, disability, empire, friendship, globalisation, the impersonal, indirection, kinship, living underground, loss, marginality, melancholia, migration, neoliberalism, pedagogy, performativity, publicity, self-shattering, shame, shyness, sovereignty, subversion, temporality and terrorism" (ibid., 182).

However, Love also suggests that before we get too excited about the expansive energies of queer, we must ask ourselves whether queer actually becomes more effective as it surveys more territory (ibid., 183). Here, the word effective seems to me quite puzzling: What are the criteria for an effective theory? It is problematic to think that when it covers more issues, questions and terrain, it becomes more effective. The often-ascribed omnipotence of queer theory can simultaneously mean it becomes flattened out and vitiated. However, and most importantly, queer theory has, like feminism, expanded the definition of what counts as sexuality. Sexuality often does not refer primarily to gender or sex; instead, sexuality can mean affect, kinship, social reproduction, the transmission of property, the division between public and private, and the construction of gender, race and nationality (see also Marcus 2005).

\section{Queering temporality}

Simultaneously with an expanding of queer theory's subject areas, attention is increasingly being paid to a problematisation of temporality, to queering temporality. This is expressed mainly as a denormalisation of temporality through its relation to desire, fantasy and wish fulfilment, but also as an increased challenging of the predictable relations between narration, linearity and teleology. As Carla Freccero has put it, now it seems that queer time is everywhere (Freccero 2011,20). The project of queering temporality thus seems to be in full swing. Hence, Annamarie Jagose wonders what difference might it make to acknowledge such intellectual traditions (not always in contexts as easily recuperated as queer), in which time has also been thought of and experienced as cyclical, interrupted, multi-layered, alterable and delayed, instead of a version of time that is always linear, teleological, reproductive and future oriented (Jagose 2007, 186-87).

In line with Jagose, Freccero asks, what then is the specificity of "queer" in relation to temporality, since not all nonlinear chronological imaginings can be understood as queer? (Freccero 2011,21-22). This question echoes Hames-García's slightly wry observation that queer is often associated with complexity. He writes: "This conflation overlooks (as queer theory tends to do) the fact that the origins of complex, intersectional thinking about sexuality (and race and gender and class) lie not in the work of canonical queer theorists in the 1990s, but in the work of feminists, predominantly women of color, in the 1970s and 1980s" (Hames-García 2011, fn. 2, 43-44). When crediting feminists for a "complex intersectional thinking about sexuality", he constructs an apparent chronological timeline between queer and feminism.

On the other hand, queer critics and theorists (such as Jack Halberstam, Elizabeth Freeman, Madhavi Menon and Elizabeth Povinelli) working at the junction of transnational spatiotemporal dislocations are advancing new discourses of queer time and space. What is most exciting here is that this problematisation of queer temporality can be seen as a way to remove queer from its transparent attachment to sexuality and link it to thinking about queer as a critique of temporal normativity rather than as sexual 
normativity specifically; the queering of temporality both is and is not connected to the matter of sexuality.

For example, Elizabeth Freeman, who moves the discussion in the direction of historiography, asks whether it is possible to think relationally across time without some concept of history (Freeman 2007, 184). For Freeman, queer relations to time are accessed through "new arrangements" of bodies, pleasures, histories and time - arrangements that she has termed erotohistoriography. She thinks that this term can capture the centrality of pleasure, especially sexual pleasure, in queer practices of documenting and encountering the past (Freeman 2010, xxiii). In problematising the relationship between queer and history, Freeman introduces the term chrononormativity (ibid., 3). With this term, she refers to the use of time for organising individual human bodies to maximum productivity people are bound to one another and made to feel coherently collective through particular arrangements of time.

Another example of queering temporality is Ellen McCallum's and Mikko Tuhkanen's discussion in the introduction to the anthology Queer Times, Queer Becomings, where they deal with temporality within a Deleuzian framework as becoming and unbecoming. They suggest that when the notion of queerness is strategically and critically posited not as an identity but as a way of becoming, temporality is necessarily always already bound up in the queer (McCallum \& Tuhkanen 2011, 8). Summing up their thoughts, they state that if queer theorists have agreed on anything, it is that, for queer thinking to have any specificity at all, it must be characterised by becoming, the constant breaking of habits, and therefore also as a constant unbecoming (ibid., 10).

Thus, the past decade or so has witnessed a rearrangement in the interplay between temporality and queer theory, i.e. a shift from a concern with an analytic interest in identity categories to a mode of examination in which the past is approached via a framework that does not position heterosexuality as the privileged cultural pattern of human intimacy and affection. According to Howard Chiang, what needs to be left behind in order for history to find a comfortable place in queer theorisation is the conviction that whatever modes of temporality queer theory can articulate, it ultimately lacks coherency or some kind of linear regularity. He thinks that the central aim of contemporary queer critique has come to be defined through two inter-related themes: first, the endless search for alternative and novel possibilities, and second, the persistent emphasis on the transformative prospect of these possibilities (Chiang 2008, 61). Chiang also emphasises along with others, for example Robyn Wiegman and Elizabeth Wilson (Wiegman \& Wilson 2015), that each radical transformation instantiated by a queer political effort actually requires a move towards, and not just away from, normativity. This means that the emphasis of queer theory should not be on the search for endless possibilities of transformation as such, but on the conditions for such a search, on scrutinising norms, their definitions and limits. This suggestion can also be interpreted as an epistemic habit of feminist self-reflexivity (Liljeström \& Peltonen 2017).

Chiang continues this thought by underlining that one of the most important things that needs to be put to rest is the idealist assumption that whatever queer theorists are deconstructing, denormalising or denaturalising, it can somehow be conceptually sealed from their simultaneous constructions, normalisations and naturalisations (Chiang $2008,61)$. The current trend of "going global" within critical thinking could be beneficial for both historical investigations and queer theory if queer scholars recognise and deal with their normalising assumptions and investments. Simultaneously, queer researchers also need to accept and handle the way in which the forms of universalising assumptions are 
making possible their own focus on the specific and the particular (ibid., 69).

In contrast to the above-mentioned examples of thinking, Janet Halley and Andrew Parker provokingly ask in their anthology After Sex? (2011), what is it like to still after the "hectic, heady and truly terrifying days of its birth" be doing queer theory, "to be working today in a tradition that has managed somehow to have acquired a past?” (Halley \& Parker 2011, 8). This questioning statement can be considered quite peculiar, and in some sense, as a negative account of the constant expansion of queer theory's subject fields. Halley and Parker seem to think that a queer theory that already has acquired a past has rather lost its freshness, which then diminishes its meaning and importance. On the other hand, the expansion of queer fields of investigation confirms its temporal continuity and stability, pointing to its ability to have accomplished a history "of its own", a status that does not have to be oppositional to creativity and newness.

\section{Historicising both queer and feminism: A brief look at the Finnish context}

Based on her interpretation of Deleuzian thinking, Claire Colebrook considers theory itself to be queer, because it aims to liberate us from a normative "image of thought". So long as we are concerned with identity, with the repetition of who we are, we remain, according to Colebrook, within constituted matter and lived time (Colebrook 2008, 18, 20). She wants to think about how theory as such might be queered, to consider theory not as a critical destabilisation of constituted terms and systems, but as a query into the appearance of terms and relations (ibid., 31). According to Colebrook, " $[\mathrm{t}]$ he possibility for a genuinely queer theory begins ... only when we challenge the normative image of life which underpins the Western image of theoria" (ibid., 23). From a Deleuzian perspective, queer encounters are, for her, not affirmations of a group of bodies who recognise themselves as other than normative, but encounters in which bodies enter into relations where the mode of relation cannot be determined in advance and where the body's becoming is also diffuse and ungrounded (ibid., 30; see also Colebrook 2009, 11-12). Therefore, queer theory should always be disturbing the normal. In line with many, both queer and feminist thinkers, I would like to apply the same thoughts to feminism, emphasising its initial adherence to problematising non-normativity.

Neville Hoad, for his part, has problematised the temporal link between feminism and queer by discussing the relationship between the prepositions "after" and "beyond". Here, the idea of beyond offers a different set of framing possibilities and limits to that of after (Hoad 2011, 136). Hence, Hoad can imagine a queer theory "after" feminism but not "beyond" feminism; according to him, queer theory needs the "before" and "during" of feminism as its enabler. However, Hoad also explicitly notices that there may be ways that feminism was also always a kind of queer knowledge project (ibid). This thought — still caught up in chronological succession - nevertheless muddles to some extent the conventional conception of temporality between queer and feminism.

In the Nordic context, gender and queer theory seem to be much more mutually entangled than we might be led to believe by the axiomatic chronology of their succession and the posture of queer theory as a deconstructive follow-up to feminism-inspired gender theory (Dahl 2016, 67-105). Looking at the entanglement of queer and feminist scholarship in the Finnish context can perhaps further problematise the rather flaccid understanding of the theoretical constructs as non-coincided, nonsimultaneous phenomena. Finnish queer thinking and feminist research 
are good examples of temporal complexities in this regard. ${ }^{8}$

In their article on queer in Finnish academia, Tuula Juvonen and Pia Livia Hekanaho mention that "[i]n Finland, the efforts to establish lesbian and gay studies in academia coincided with a paradigmatic shift towards queer studies. What may have started in the 1980s as work based on identitarian positioning has in the meantime, in the texts of many scholars, transformed into a more nuanced understanding of the various discursive practices informing the creation of genders and sexualities" (Juvonen \& Hekanaho 2008). Juvonen and Hekanaho consider this transition to be more an organic than an antagonistic one, possibly also because nobody had academic positions to defend in those early days of Finnish queer research, and "postgraduate studies were taken up out of passion and intellectual curiosity rather than due to a conscious career decision", as they straightforwardly declare (ibid.). They also give a positive evaluation of practices at Women's Studies centres (in Jyväskylä, Helsinki and Turku) to "have considered queer studies important enough to include them in the core curriculum. This has not necessarily translated into steady teaching positions for queer scholars in those universities" (ibid.). Their conclusion is that the role of feminist Women's Studies has been crucial for establishing and supporting teaching and academic supervision in queer studies. For queer studies to survive, it is therefore also vital to strengthen the position of Women's Studies in universities through collaborative efforts (ibid.).

8 I do not consider the Finnish context as in any way self-evident, and I do not view it as exceptional: the rigid tradition of methodological nationalism is not, in our current world, at all helpful in thinking of spatial/national contexts and their specificities (see Beck 2007; Chernilo 2011). Instead, such new images of thought that respect diversity and constitute communities (national, ethnic and others) should be activated across multiple locations (see Braidotti 2013). The local/national is not a point of departure for thinking, but rather a research subject.
Discussions about the scope, limits and main focus or topics of queer research in the Finnish context, where — as noted - the emergence of queer and gay and lesbian studies has been considered as temporally concurrent, have been scarce. However, in a discussion published in the Finnish queer studies journal $S Q S$ in 2008, queer theory was also underlined precisely as a methodological approach, as an application to research questions concerning different minority sexual and gendered identities (Hekanaho et al. 2008). ${ }^{9}$ When it comes to the specific concerns in the shift to queer thinking from a small-scale, constricted identityfocused type of gay and lesbian research, Harri Kalha considers this transition to have been quite delicate. He also notices that not even the academic queer audience was completely ready or willing to discuss things outside traditional categories (Kalha 2006, 114).

Based on the temporal narrowing or condensation of feminism/Women's/ Gender Studies and queer research in the Finnish context, we can see two simultaneous, temporally outspread, "turns": one queer turn in feminism, but also some sort of slight feminist turn in queer research. In connection to the latter, feminism should be understood in multiple and differing ways. If accepting this, we can ask if there is any point in distinguishing between the scholarly positions attached to these theoretical strands if "all of us" nevertheless primarily and continuously critically are doing research on various identity constructions and categories. Besides, in terms of selfnaming, who is then a queer scholar, a scholar of homosexuality (a gay and lesbian studies scholar) and/or a gender studies scholar or feminist scholar? What does this naming imply about understanding Gender Studies as a field-formative umbrella term for diverse scholarly positions?

9 Harri Kalha and Tuula Juvonen refer to a certain subject matter or topic of "queer research". They do this without any further specification as regards its content (Kalha \& Juvonen 2011, 52). 


\section{By way of conclusion}

One of queer theory's most valuable contributions and one that establishes an important link to feminist work on sexuality has been to demonstrate how homosexuality and heterosexuality mutually define each other. ${ }^{10}$ Especially in Gender Trouble (1990), Judith Butler showed that definitions of gender assume definitions of sexuality. If sexuality is one of the elements making up the sign "woman", and if the goal of feminist theory is to challenge what we mean by woman, then queer theory with its focus especially on sexuality is a crucial tool for academic feminism. Perhaps someone might still argue that by undermining gender as a stable category, queer theory undermines feminism, which is reliant on the concept of woman. As Sharon Marcus has noted, this fear is groundless for two reasons. First, queer theory does not abandon the concept of gender, since "deviant" sexuality depends on taking a stand on assigning gender to oneself and to the people to whom one is sexually attracted. Second, since feminism is by definition invested in changing women's social and political positions, the concept of woman upon which feminism rests is mobile, not static, and thus not at risk from the kinds of elasticity that both queer and trans theory ascribes to gender (see Marcus 2005, 200, footnote 9). This remark is totally in line and consistent with Denise Riley's thoughts on feminism as always being critical of its foundational category of "women". In her classic and ground-breaking book 'Am I That Name?': Feminism and the Category of "Women" in History (1988), she understands feminism as exhibiting a fundamental mistrust of this category by emphasising the indeterminacy and impossibility of "women" (Riley 1988, 5, 113).

As is true of field formations of every kind, one becomes a queer studies scholar as well as a feminist scholar by participating in its discussions,

10 See Rubin (1984), Sedgwick (1990) and Wittig (1992). theoretical meanings, discursive tropes, methodological practices and citational histories. How entirely paradoxical then that reproducing the critique of normativity is one of the surest ways to secure belonging in the field. Annamari Vänskä has demanded a queering also of disciplines, stating that it is not enough that we deconstruct sources and materials, question the epistemology of the closet and make visible the implicit self-sufficiency and naturalness of the hegemonic heterosexuality of our culture. We also must politicise and queer on a more institutional level those academic spaces where dogmas are taught without questioning heteronormativity. Therefore, she underscores that a louder voice should be raised about the ways that academic disciplines draw lines between being inside and outside, between public and private knowledge, even between essential and marginal knowledge (Vänskä 2008, 65).

To sum up, it seems that shifts and moves both within and between feminism and queer thinking, linked to the challenges presented by trans scholarship, take care of dismantling identity categories and, to some extent, multiplying identities. How then can feminist and queer knowledge production stimulate the antinormative without to a certain degree being committed to the normative? These questions are challenging and seem difficult to answer, in part because antinormativity is ultimately not about the object of study in itself, but about the relationship between the motivation and desire that separates, prioritises and disciplines it. In connection with this, we should perhaps put more effort into continuing to think about the linkages or nodal points between feminist and queer theories, about criteria by which different non-linear temporalities might meaningfully be brought together.

I am grateful to the SQS editors and the two anonymous reviewers for their sharp and meticulous comments on my text: they certainly helped me to specify my arguments!

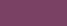




\section{References}

Ahmed, Sara. 2017. Living a Feminist Life. Durham: Duke University Press.

Beck, Ulrich. 2007. "The Cosmopolitan Condition. Why Methodological Nationalism Fails". Theory, Culture \& Society 24(7-8): 286-290.

Berger, Anne E. 2014. The Queer Turn in Feminism. Identities, Sexualities, and the Theater of Gender. New York: Fordham University Press.

Butler, Judith. 1990. Gender Trouble. Feminism and the Subversion of Identity. New York \& London: Routledge.

Butler, Judith. 1993. Bodies that Matter. On the Discursive Limits of "Sex". New York: Routledge.

Butler, Judith. 1994. “Against Proper Objects”. differences 6(2-3): 1-26.

Butler, Judith. 2004. Undoing Gender.New York: Routledge.

Braidotti, Rosi. 2013. "Becoming-World". In After Cosmopolitanism, edited by R. Braidotti, P. Hanafin and B. Blaagaard, 8-27. New York \& London: Routledge.

Chaudhry, V Varun. 2019. “Centering the 'Evil Twin': Rethinking Transgender in Queer Theory". GLQ 25(1): 45-50.

Chernilo, Daniel. 2011. "The Critique of methodological nationalism: Theory and history". Thesis Eleven 106 (1): 98-117.

Chiang, Howard H. 2008. "Empire of Desires: History and Queer Theory in an Age of Global Affect". Critical Studies in History 1: 50-71.

Chu, Andrea Long and Emmett Harsin Drager. 2019. "After Trans Studies". Transgender Studies Quarterly 6(1): 103-116.

Colebrook, Claire. 2008. "How Queer Can You Go? Theory, Normality and Normativity". In Queering the Non/Human, edited by N. Giffney, and M. J. Hird, 17-34. Aldershot: Ashgate.

Colebrook, Claire. 2009. "On the Very Possibility of Queer Theory". In Deleuze and Queer Theory, edited by C. Nigianni, and M. Storr, 11-23. Edinburgh: Edinburgh University Press.

Dahl, Ulrika. 2016. "Between Familiar Differences and American Tunes: The Geopolitical Grammar of Nordic Gender Studies in an Age of Europeanisation". In The Geopolitics of Nordic and Russian Gender Research 1975-2005, edited by Ulrika Dahl, Marianne Liljeström, and Ulla Manns. 67-132. Södertörn: Södertörn Academic Studies 66.

de Lauretis, Teresa. 1991. "Queer Theory: Lesbian and Gay Sexualities. An Introduction". differences 3(2): iii-Xviii.
Edelman, Lee. 2004. No Future. Queer Theory and the Death Drive. Durham: Duke University Press.

Elam, Diane, and Robyn Wiegman. 1995. "Contingencies". In Feminism Beside Itself, edited by D. Elam and R. Wiegman, 1-8. New York \& London: Routledge.

Eng, David, Judith Halberstam, and José Muñoz. 2005. "Introduction What's Queer about Queer Studies Now?".Social Text 23(3-4): 1-17.

Espineira, Karine, and Marie-Hélène/Sam Bourcier. 2016. "Transfeminism. Something Else, Somewhere Else". TSQ 3(1-2): 84-94.

Freccero, Carla. 2011. "Queer Times". In After Sex?, , edited by J. Halley and A. Parker, 17-26. Durham: Duke University Press.

Freeman, Elizabeth. 2007. "Theorizing Queer Temporalities: A Roundtable Discussion". GLQ 13(2-3): 177-195.

Freeman, Elizabeth. 2010. Time Binds. Queer Temporalities, Queer Histories. Durham: Duke University Press.

Garber, Linda. 2001. Identity Poetics. Race, Class, and the Lesbian-Feminist Roots of Queer Theory. New York: Columbia University Press.

Giffney, Noreen,, and Myra J. Hird. 2008. "Introduction: Queering the Non/ Human". In Queering the Non/Human, edited by N. Giffney and M. J. Hird, 1-16. Aldershot: Ashgate.

Halley, Janet, and Andrew Parker. 2011. "Introduction". In After Sex?, edited by J. Halley and A. Parker, 1-16. Durham: Duke University Press.

Halperin, David.1995. Saint Foucault: Towards a Gay Hagiography. Oxford: Oxford University Press.

Hames-García, Michael. 2011. "Queer theory revisited". Gay Latino Studies: A Critical Reader, 19-45. Durham: Duke University Press.

Hayes,Jarrod, Margaret R. Higonnet,and William J. Spurlin. 2010. "Comparing queerly, queering comparison. Theorizing identities between cultures, histories and disciplines". In Comparatively Queer. Interrogating Identities across Time and Cultures, edited by J. Harrod, M.R. Higonnet, and W.J. Spurlin, 1-19. Basingstoke: Palgrave.

Hekanaho, Livia etal. 2008. "Pervot arkistot ja kaapit. Tutkimusaineistojen toisinajattelemisesta". SQS 2: 58-68.

Hennessy, Rosemary. 1993. "Queer Theory: A Review of the 'Differences' Special Issue and Wittig's 'The Straight Mind”. Signs 18(4): 964-973.

Hirsch, Marianne, and Evelyn Fox Keller. 1990. "Conclusion: Practicing Conflict in Feminist Theory". In Conflicts in Feminism, edited by M. Hirsch and E.F. Keller, 370-380. New York \& London: Routledge. 
Hoad, Neville. 2011. "Queer Theory Addiction". In After Sex?, edited by J. Halley and A. Parker, 130-141. Durham: Duke University Press.

Jagose, Annamarie. 2007. "Theorizing Queer Temporalities: A Roundtable Discussion”. GLQ 13(2-3): 177-195.

Jagose, Annamarie. 2009. “Feminism's Queer Theory”. Feminism \& Psychology 19(2): 157-174.

Juvonen, Tuula, and Livia Hekanaho. 2008. "Leaving a Glorious Future Behind? Queer in Finnish Academia". Trikster. Nordic Queer Journal 2.

Kalha, Harri. 2006. "Queer-toimijuus skitsofreniana. Homostelun kieli, tunnustuksellisuus ja tutkijan julkilausuttu minä". SQS 2: 106-115.

Kalha, Harri, and Tuula Juvonen. 2011. "Queer-tutkijan ura - onko sitä?”. SQS 1: $52-57$.

Kaplan, Carla. 1992. "The Language of Crisis in Feminist Theory". The Bucknell Review 36(2): 68-80.

Kekki, Lasse. 2003. From Gay To Queer. Gay Male Identity in Selected Fiction by David Leavitt and in Tony Kushner's Play Angels in America I-II. Frankfurt am Main: Peter Lang.

Koivunen, Anu,and Marianne Liljeström. 1996. Avainsanat. 10 askelta feministiseen tutkimukseen. Tampere: Vastapaino.

Liljeström, Marianne, and Salla Peltonen. 2017. "On Feminist Epistemic Habits and Critique". Feminist Encounters: A Journal of Critical Studies in Culture and Politics 1(1).

Love, Heather. 2011a. "Queers_-This”. In After Sex?, edited by J. Halley and A. Parker, 180-191. Durham: Duke University Press.

Love Heather. 2011b. "Introduction" to a special issue on Gayle Rubin, "Rethinking Sex". GLQ, 17(1): 1-14.

Luciano, Dana, and Mel Y. Chen. 2015. "Introduction. Has the Queer ever been Human”. GLQ 21(2-3): 183-207.

Marcus, Sharon. 2005. "Queer Theory for Everyone: A Review Essay”. Signs 31(1): 191-218.

Marinucci, Mimi. 2016. Feminism is Queer: The Intimate Connection between Queer and Feminist Theory. London, UK: Zed Books.

Martin, Biddy. 1994. "Sexualities without Genders, and Other Queer Utopias". Diacritics 24(2-3): 104-121.

McBean, Sam. 2016. Feminism's Queer Temporalities. New York \& London: Routledge.
McCallum, Ellen L., and Mikko Tuhkanen. 2011. "Becoming Unbecoming. Untimely Mediations". In Queer Times, Queer Becomings, edited by E.L. McCallum and M. Tuhkanen, 1-21. Albany: SUNY Press.

Menon, Madhavi. 2015. Indifference to Difference: On Queer Universalism. Minneapolis: University of Minnesota Press.

Richardson, Diane etal. (eds.). 2006. Intersections Between Feminist and Queer Theory. Basingstoke: Palgrave.

Richardson, Diane. 2006. "Bordering Theory". In Intersections Between Feminist and Queer Theory, edited by D. Richardson, J. McLaughlin and M.E. Casey, 19-37. Basingstoke: Palgrave.

Riley, Denise. 1988. 'Am I That Name?': Feminism and the Category of 'Women' in History. London: Macmillan.

Rosenberg, Tiina. 2003. Queerfeministisk agenda. Stockholm: Bokförlaget Atlas.

Rossi, Leena-Maija. 2017. "Hauras, korjaava ja parantumaton queer - katse ylpeyden, normatiivisuuden ja (uus)häpeän aikoihin”. SQS 1: 1-18.

Rubin, Gayle. 1984. "Thinking Sex: Notes for a Radical Theory of the Politics of Sexuality". In Pleasure and Danger. Exploring Female Sexuality, edited by C.S. Vance, 267-319. Boston: Routledge.

Rudy, Kathy. 2000. “Queer Theory and Feminism”. Women's Studies 29: 195-216

Sedgwick, Eve Kosofsky. 1990. Epistemology of the Closet. Berkeley: University of California Press.

Sedgwick, Eve Kosofsky. 1994. Tendencies. Durham: Duke University Press.

Stryker, Susan. 2004. “Transgender Studies: Queer Theory’s Evil Twin”. GLQ 10(2): 212-215.

Stryker, Susan,Paisely Currah, and Lisa Jean Moore. 2008. "Introduction: Trans-, Trans, or Transgender? Women's Studies Quarterly 36(3-4): 11-22.

Stryker, Susan, and Paisely Currah. 2014. "Introduction”. Postposttranssexual. Key Concepts for a Twenty-First-Century Transgender Studies. Transgender Studies Quarterly 1(1-2): 1-18.

Traub, Valerie. 2010. “Afterword: Comparisons worth making”. In Comparatively Queer. Interrogating Identities across Time and Cultures, edited by J. Harrod etal., 215-223. Basingstoke: Palgrave.

Livia Hekanaho etal. 2008. "Pervot arkistot ja kaapit. Tutkimusaineistojen toisinajattelemisesta". SQS 2: 58-68.

Weed, Elizabeth and Naomi Schor. (eds.). 1997. Feminism Meets Queer Theory (Books from differences) Bloomington: Indiana University Press. 
Wiegman, Robyn. 2000. “Feminism's Apocalyptic Futures”. New Literary History 31(4): 805-825.

Wiegman, Robyn. 2004. “Dear Ian”. Duke Journal of Gender Law \& Policy 11(93): 93-120.

Wiegman, Robyn. 2012. Object Lessons. Durham: Duke University Press.

Wiegman, Robyn, and Elizabeth Wilson. 2015. "Introduction: Antinormativity's Queer Conventions". differences 26(1): 1-25. Press. 